\title{
IMPACT ON THE APPLICATION OF INSULATION IN BUILDINGS TO ACHIEVE THERMAL COMFORT (A CASE STUDY: LAUSER OFFICE BUILDING IN BANDA ACEH)
}

\author{
Nova Purnama Lisa \\ Department of Architecture, Faculty of Engineering \\ Malikussaleh University, Lhokseumawe, Aceh \\ e-mail: nova.ars22@gmail.com \\ Zuraihan \\ Department of Architecture, Al Muslim University \\ Biereun, Aceh \\ e-mail: re.ars00@yahoo.com
}

Received: October $26^{\text {th }} 2014$; Accepted: December $5^{\text {th }} 2014$; Available Online: December $15^{\text {th }} 2014$

\begin{abstract}
From the results of research studies on the impact of the use of insulation in buildings, reducing solar radiation on buildings to improve indoor comfort by applying the Principles of radiation reduction in buildings naturally using insulation application that serves as an insulator against the building materials, use of thermal insulation in particular mounted on the roof of the building and the walls are located on second floor and the third floor Lauser office building, Calculate the cooling load for each room that was on second floor and the third floor based on the geographical location or position of the building, climate data, building material data, and the intensity of the spatial characteristics which include lighting, solar radiation, user activity and electrical appliances being used. The calculation is done with the help of Ecotech v.5, 2011. The location and position on the third floor of a building with a flat roof cast concrete, so that the heat absorbed by the platform, and two times greater than the amount of heat radiation is absorbed by the material in the direction of the light falling the sun is at an angle $<30^{\circ} \mathrm{C}$. The simulation results on the building with the addition of thermal insulation on all walls and the roof of the inside of the foam material ultrafolmadehid, without changing the model building and similar activities in accordance with the existing condition and the condition of the room using the air conditioner at a temperature of $18-26^{\circ} \mathrm{C}$, indicating a decrease in cooling load signifinikan in any space reaches $40 \%$ of the total cooling load required on the lauser office building. Comparing the simulation results Ecotech temperature v.5 2011 with field measurements as a validation of the simulation results in order to achieve thermal comfort in buildings and can menggurangi use energy consumption in buildings and can be used as a reference in planning space-based conditioning systems energy efficient.
\end{abstract}

Keywords: thermal insulation, thermal comfort, office building, insulator, cooling load

\begin{abstract}
Abstrak
Dari hasil penelitian studi terhadap dampat dari penggunaan insulasi pada bangunan mengurangi radiasi matahari pada bangunan untuk meningkatkan kenyamanan dalam ruang dengan menerapkan prinsip -prinsip pengurangan radiasi pada bangunan secara alami dengan menggunakan penerapan insulasi yang berfungsi sebagai isolator terhadap material bahan bangunan, Penggunaan thermal insulator dipasang pada bagian atap bangunan dan dinding yang berada di lantai 2 dan 3 lauser office building, Menghitung beban penyejukan (cooling load) untuk tiap-tiap ruang yang berada di lantai 2 dan 3 berdasarkan letak geografis atau posisi gedung, data iklim, data material bangunan, dan karakteristik ruang yang meliputi intensitas pencahayaan, radiasi matahari, aktivitas pengguna dan peralatan listrik yang digunakan. Perhitungan tersebut dilakukan dengan bantuan program Ecotech v.5 2011. Letak dan posisi pada lantai 3 bangunan dengan atap datar cor beton, sehingga panas yang diserap oleh bidang datar, dua kali lebih besar dibandingkan dengan jumlah radiasi panas yang diserap oleh material dengan arah jatuh sinar matahari yang membentuk sudut lebih < 30 oC. Hasil simulasi pada bangunan dengan penambahan insulasi termal pada seluruh dinding dan atap bagian dalam dengan material foam ultrafolmadehid, tanpa merubah model bangunan dan aktifitas yang sama sesuai dengan kondisi eksisting dan kondisi ruang menggunakan AC pada temperatur $18-26^{\circ} \mathrm{C}$, menunjukkan penurunan beban cooling load yang signifinikan pada setiap ruang mencapai $40 \%$ dari total beban penyejukan yang dibutuhkan pada gedung Lauser office building. Membandingkan temperatur hasil simulasi Ecotech v.5 2011 dengan pengukuran lapangan sebagai validasi hasil simulasi sehingga tercapai kenyamanan termal pada bangunan dan dapat menggurangi penggunaan konsumsi energi pada bangunan serta dapat dijadikan sebagai salah satu referensi dalam perencanaan sistem pengkondisian ruang yang berbasis hemat energi.
\end{abstract}

Kata kunci: insulasi termal, kenyamanan termal, gedung perkantoran, isolator beban penyejuk 


\section{Introduction.}

Global warming is happening now quite diverse impacts on human life. The rise in air temperature becomes one of reducing the impact of human thermal comfort zone of space in the building. Building as the primary means of meeting the needs of human beings, must meet the criteria of human comfort zone, where thermal comfort into one integral part. There are several factors that determine the achievement level of thermally comfort in a building, the impact on the use of thermal insulation. The latest technological developments to support the use of thermal insulation in buildings is one application to solve the problem of heat in homes, especially in tropical buildings have solar lighting intensity is high enough.

The use of thermal insulators mounted on the roof of the house that act as inhibitors of the rate of heat transfer from the outside into the building and vice versa, so that the heat of the sun until the skin of the building can be minimized so that the temperature of the space inside the building can still be maintained[1].

The development of a city is always synonymous with the many building that functioned as a forum for individuals or human activity. The existence of the building will affect the occupants and users in it. But sometimes laying site and building orientation on the sun and the elements of the material that is applied to the building is also very closely related to the comfort room temperature[2].

Savings energy of a building requires information relating to the major source of energy waste, such as the use of cooling systems with redundant power, or position of the wrong placement of lighting glass, where the orientation of the building, the characteristics of building materials, placement of air vents building as the air circulation inside the building, the shape of the roof of the building affects the heat accumulation in the space below. Energy consumption continues to increase with limited availability, requires that we are able to manage and use energy very efisein possible to avoid energy waste and costs[3].

This research, the building is used as the object of research is Lauser office buildings. The building is located at the confluence Shiite university campus, precisely in the campus complex Darussalam, Banda Aceh. Banda Aceh is a city located on the coast with high air temperatures during the day. Based on climatological data for the area of Banda Aceh which was obtained from the Meteorological Station Blang Bintang air temperature in Banda Aceh in 2010, ranging between $34-36^{\circ} \mathrm{C}$. This is a very big problem to achieve comfort in the space to the tropics.

the Indonesian National Standard (SNI)[4][5], Energy Consumption is the energy used by buildings in a certain time period and the multiplication of power and operating time.
Therefore, An overview of the assessment and calculate the energy consumption of the office building that uses Lauser thermal insulation as a way to provide comfort to the environment in a concrete-roofed buildings, especially buildings, by applying the principles and ways of actively cooling the building is expected to reduce energy consumption on artificial weather, it is very important to minimize the energy consumption and can realize an energy-efficient building and environmentally friendly.

\section{Definition of Termal Insulation}

Isolation is defined as a material or combination of materials that inhibit the flow of heat. Materials can be adapted to any shape, size or surface. Various finishes are used to protect the insulation from mechanical and environmental damage, and to improve appearance[6].

The basic principle of thermal insulation to prevent excessive heat loss due to heat transfer by providing insulation or barriers in the path of heat flow. The presence of insulating able to impact some of the heat does not move, so the temperature in the room can be in control[1].

The purpose of proofing aims to save energy, as well as to protect and comfort the human impact. In addition, the insulation also aims to regulate the processes associated with temperature, protect from fire to reduce noise and shock.

This study was limited to the assessment of energy consumption of air conditioning systems and energy savings, especially building roofed concrete by applying the techniques of active cooling is lacking in order to optimize energy consumption building by conducting energy audits as a manifestation of an energy efficient building. Energy Audit is to know the "Images Energy Use" and look for efforts to increase the efficiency of energy use. Energy audit is used to calculate the amount of energy consumption and identify ways to savings. Energy conservation, is an effort to minimize the energy consumption to a need for energy waste can be avoided. Energy management, that any attempt to regulate and manage the use of energy in buildings as efficiently as possible without reducing the level of comfort in the residential environment or productivity in the workplace[7].

\section{Lauser Office Building}

The specially of the Lauser Office Building that do not use the roof as a patron of the building, when compared to other buildings, this building is different from the other buildings around it. Characteristics of the building is closed and use air conditioning in all rooms, flat roof model and walls of the building using concrete materials with glass on the walls of the building, into an interesting study to do research, to see whether the level of comfort in building a model building model cast 
concrete building with a roof that has a high comfort level or not.

Zone research in auditing and analyzed are two zones and three zones, namely the second floor and the third floor. Selection is based on the orientation of the building zone to sunlight. On second floor and the third floor. Sunlight received by the building absorb maximally, (Figure.4)

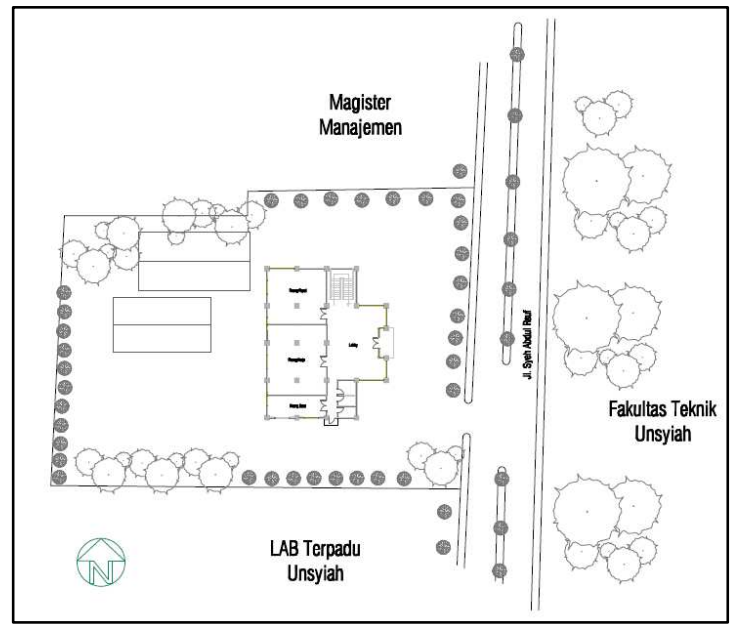

Figure 1. Lay Out Plan of the Lauser Office Building (Source: Observation, 2012)

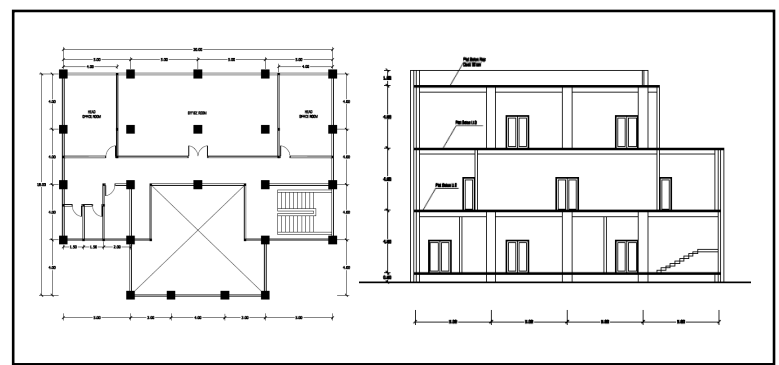

Figure 2. second floor map of the Lauser Office Building and section A-A ( Source: Observation, 2011)

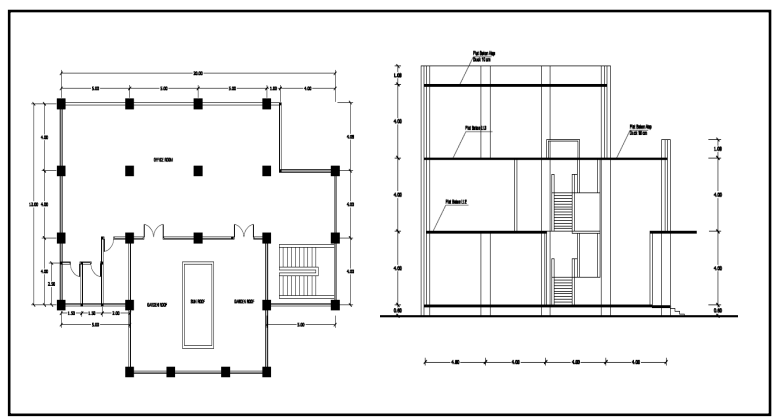

Figure 3. third floor map of the Lauser Office Building and section B-B (Source: Observation, 2012)

Tabel. 1 The properties of the building materials of the Leuser Office Building

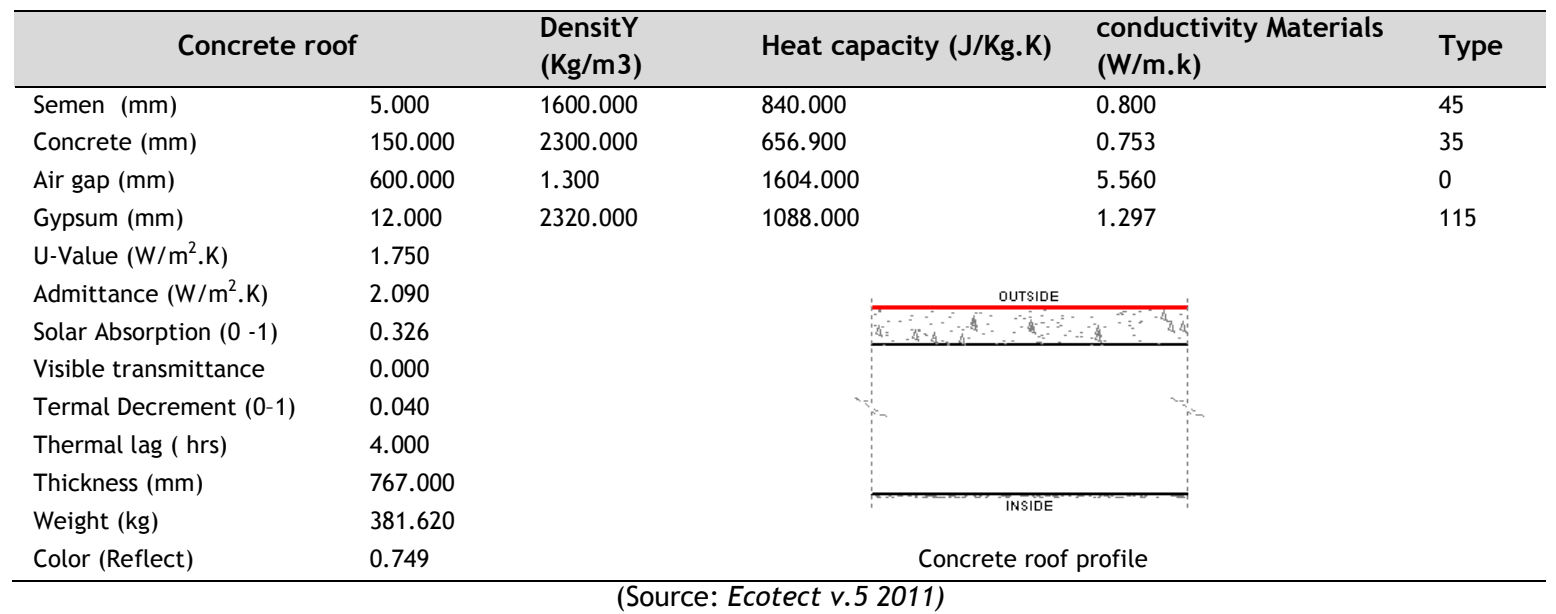

Value properties of the building materials used building Lauser office building can be seen in the following (table.1). Use of the material focused on the second floor and the third floor away from Lauser office building as object of studies. 
Tabel. 2 The properties of the building materials of the Leuser Office Building

\begin{tabular}{|c|c|c|c|c|c|}
\hline \multicolumn{2}{|l|}{ Plaster Brick Walls } & \multirow{2}{*}{$\begin{array}{l}\begin{array}{l}\text { Densitas } \\
(\mathrm{Kg} / \mathrm{m} 3)\end{array} \\
1250.000\end{array}$} & \multirow{2}{*}{$\begin{array}{l}\text { Kapasitas Panas (J/Kg.K) } \\
1088.000\end{array}$} & \multirow{2}{*}{$\begin{array}{l}\text { Konduktivitas Bahan } \\
\text { (W/m.k) } \\
0.431\end{array}$} & \multirow{2}{*}{$\begin{array}{r}\text { Type } \\
85\end{array}$} \\
\hline Plester semen luar $(\mathrm{mm})$ & 10.000 & & & & \\
\hline Batu bata (mm) & 110.000 & 2000.000 & 836.800 & 0.711 & 25 \\
\hline $\begin{array}{l}\text { Plaster semen dalam } \\
(\mathrm{mm})\end{array}$ & 10.000 & 1250.000 & 1088.000 & 0.431 & 85 \\
\hline U-Value $\left(\mathrm{W} / \mathrm{m}^{2} . \mathrm{K}\right)$ & 2.640 & & & & \\
\hline Admittance $\left(\mathrm{W} / \mathrm{m}^{2} . \mathrm{K}\right)$ & 4.380 & & & & \\
\hline Solar Absorption (0 -1) & 0.418 & & & & \\
\hline Visible transmittance & 0.000 & & & $\underset{\underline{\omega}}{\underline{\omega}}$ & \\
\hline Termal Decrement (0-1) & 0.700 & & & & \\
\hline Thermal lag ( hrs) & 3.000 & & & & \\
\hline Thickness (mm) & 130.000 & & & & \\
\hline Weight $(\mathrm{kg})$ & 2352459.000 & & & & \\
\hline Color (Reflect) & 0.569 & & Profil Dindi & & \\
\hline
\end{tabular}

(Source: Ecotect v.5 2011)

\section{Result and Discussion}

Cooling load calculation is done as a basis for determining the amount of air conditioning capacity required to achieve the desired level of comfort. From the calculation, it is known that cooling load of each space is different from one another (Table 3 ). On third floor (room 7), the Lobby and room 6, a large cooling load required of each is $80.88 ; 213.24$. The values are higher compared to the value of cooling load in the other spaces. The main thing causes big differences in the space cooling load requirement is space- space with a concrete roof platform that directly receives exposure to solar radiation receiving more heat than the sheltered spaces or receive direct sunlight shadow (see Figure 4\&5).

The use of thermal insulation used in roofs and walls. Thermal insulation used is Ultrafolmadehid Foam. Foam PE Foam insulation Ultrafolmadehid materials are free of fiber or fiber that is very well designed to protect the roofs of houses, factories and buildings from the heat caused by solar radiation, conduction of sound from the roof of the building and outside the building effectively and efficiently.

insulation can also function as a silencer and regulate the humidity in the room so that the air inside feels cool and comfortable.

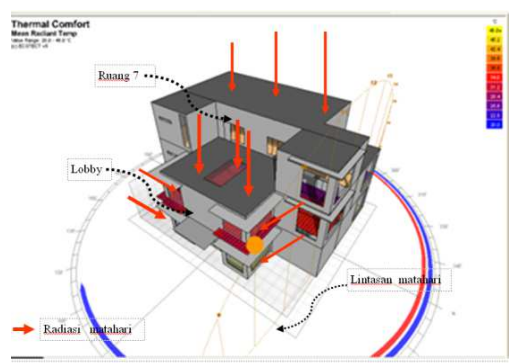

Figure 4. Orientasi Building on radiation ( Source: Observation, 2012)

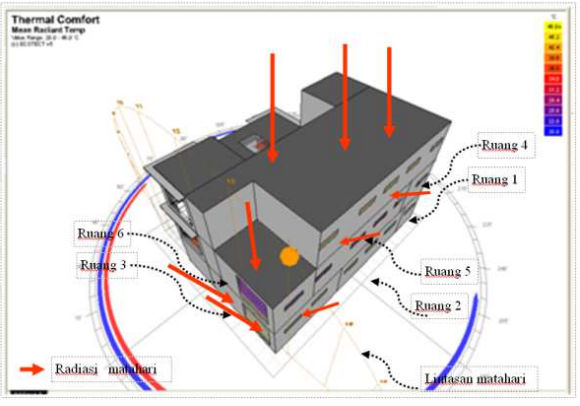

Figure 5. Orientasi Building on radiation ( Source: Observation, 2012)

Table 3. Comparison of cooling load with the addition of insulation material

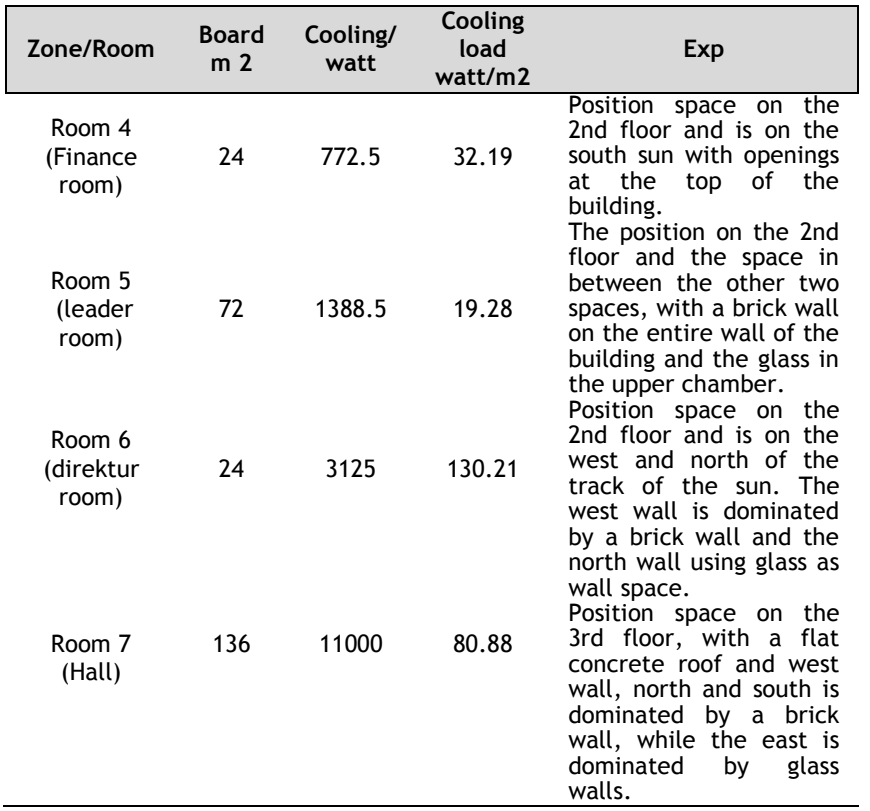


Based on the simulation results ecotect v.5, 2011, on the the building LIF, for buildings with flat roofs characteristic of cast concrete, brick walls and windows with words closed air circulation system, the cooling load demand load or cooling load should be required to achieve the desired room temperature. Due to the large cooling load required by each space is different, therefore, to improve energy efficiency building, need to be evaluated and cooling load calculations necessary to dispose of the accumulated heat from the environment (external heat gain) and the accumulation of internal heat gain, so as to determine the different causes and search for the right energy saving system. (Table.4)

Table 4. Comparison of cooling load with the addition of insulation material

\begin{tabular}{cccc}
\hline 2nd Floord & \multicolumn{2}{c}{ Cooling load } \\
\hline \hline \& 3rd Floor & $\begin{array}{c}\text { Existing } \\
\text { (watt) }\end{array}$ & $\begin{array}{c}\text { Insulasi app } \\
\text { (watt) }\end{array}$ \\
\hline 2nd floor & & & \\
Room 4 & 24 & 772.5 & 503 \\
Room 5 & 72 & 1388.5 & 1331 \\
Room 6 & 24 & 3125 & 2371 \\
& & & \\
3 rd floor $_{\text {Room 7 }}$ & 136 & 11000 & 6679 \\
\hline \multicolumn{4}{c}{ (Source: Observation, 2012) }
\end{tabular}

From the results of research studies on the impact of the use of insulation in buildings, reducing solar radiation on buildings to improve indoor comfort by applying the Principles of radiation reduction in buildings naturally using insulation application that serves as an insulator against the building materials, use of thermal insulation in particular mounted on the roof of the building and the wall in the second floor and the third floor of the office building Lauser, Calculate the cooling load for each room that was on the second floor and third floor based on the geographical location or position of the building, climate data, building material data, and spatial characteristics that include lighting intensity, solar radiation, user activity and electrical appliances being used. The calculation is done with the help of Ecotech v.5, 2011. The location and position on the third floor of a building with a flat roof cast concrete, so that the heat absorbed by the platform, and two times greater than the amount of heat radiation is absorbed by the material in the direction of fall sunlight at an angle over $<30^{\circ} \mathrm{C}$. The simulation results on the building with the addition of thermal insulation on all walls and the roof of the inside of the foam material ultrafolmadehid, without changing the model building and similar activities in accordance with the existing condition and the condition of the room using the air conditioner at a temperature of $18-26^{\circ} \mathrm{C}$, indicating a decrease in cooling load signifinikan in any space reaches $40 \%$ of the total required cooling load on the building Lauser Office building. Comparing the simulation results Ecotech temperature v.5 2011 with field measurements as a validation of the simulation results in order to achieve thermal comfort in buildings and can decrease use energy consumption in buildings and can be used as a reference in planning space-based conditioning systems energy efficient on lauser building office.

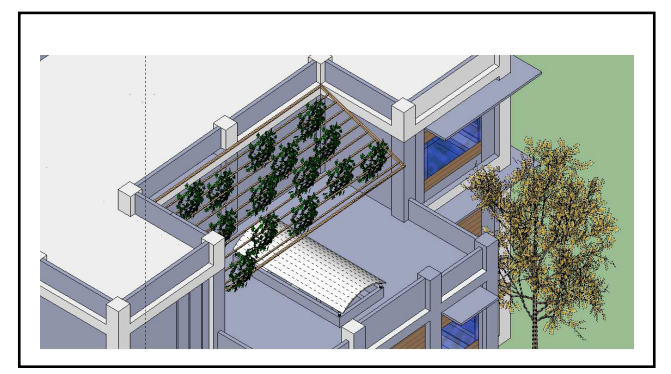

Figure 5. The addition of green canopy and roof insulation. ( Source: Observation, 2012)

The location and spatial position 7 on the 3 rd floor of the building with a flat roof cast concrete, so that the heat absorbed by the platform, and two times greater than the amount of heat radiation is absorbed by the material falling towards the sun at an angle is $<30^{\circ} \mathrm{C}$. In addition, the amount of incoming solar radiation from the transparent areas windows and doors on the eastern position of the sun and flat cast concrete from the 2 nd floor (lobby) adds the accumulated heat into the building. To reduce the rate of heat transfer from the building materials can be done by:

1. The addition of insulation in the roof and walls of the building by using a material that is able to absorb the heat transfer by convection, conduction and radiation.

2. Shadowing the green canopy (plant), with a cover of vines and shading can reduce the elevated temperatures in space $1{ }^{\circ} \mathrm{C}$ with a thin roof insulation condition. Cross ventilation (cross ventilation), on windows 7 space or other openings on two different sides will encourage the wind to get into the space so that the space will be more cool and not stuffy.

3. Based on the simulation results ecotect v.5, 2011, with the additional criteria of insulation on the roof and walls of the chamber 7 imagery with a green canopy can lower cooling load by $33.45 \%$ of the total cooling load required in room 7.

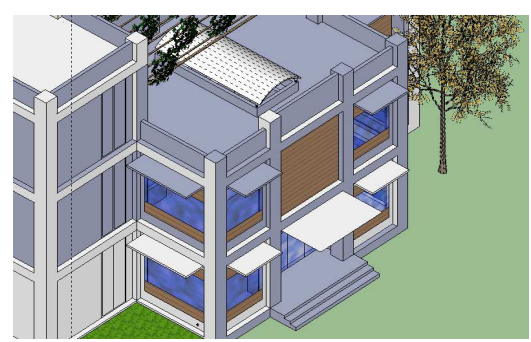

Figure 6 . The addition of green canopy and roof insulation.( Source: Observation, 2012) 
To reduce the rate of heat transfer from the building materials and windows and sky light, can be done by:

1. The addition of insulation in the roof and walls of the building by using a material that is able to absorb and reduce the heat transfer by convection, conduction and radiation. Cross ventilation, the lobby window at the top and bottom of the window on two different sides will encourage the wind to get into the space so that the space will be more cool and not stuffy.

2. Shadowing of plants and shade (sun Shanding) enters the building from the sun's rays coming from the east (in the morning until noon) and the west (in the afternoon and evening) were able to reduce the radiation in the direction of the wall. Based on the simulation results ecotect v.5, 2011, in the lobby with an improved model of air circulation in the window by applying the cross-circulation system (cross ventilation), the burden of cooling load down $44.4 \%$ of the total cooling load requirements.

\section{Conclusion}

The simulation results building with the addition of thermal insulation on all walls and the roof of the inside of the foam material ultrafolmadehid, without changing the model building and similar activities in accordance with the existing condition and the condition of the room using the air conditioner at a temperature of $18-26{ }^{\circ} \mathrm{C}$, indicating a decrease in cooling load signifinikan in any space reaches $40 \%$ of the total cooling load required to Lauser office building. Of the several models have been simulated, to lower the cooling load load, the characteristics of the building with the building oriented to the east and the west path of the sun, brick walls, flat roofs with cast concrete and glass enclosed air circulation system, can be done several ways.
For spaces that do not directly receive solar radiation indirectly and with a closed air circulation system, the addition of insulation material is very effective to reduce the cooling load of the load, so that an air-conditioning capacity required can be reduced, but the level of comfort in the room can be achieved.

\section{References}

[1] Givoni and Baruch, Man, Climate and Architecture. London: Applied Science Publishers Ltd, 1976, pp. 63-162.

[2] G. Lippsmeier, Tropenbau Building in the Tropics. Jakarta: Erlangga, 1994.

[3] M. Hanum and M. Chairul, "Efisiensi Energi Pada 'Smart Building' Untuk Arsitektur Masa Depan," in Seminar Nasional, AVoER ke 3, 2011.

[4] S. 03-6389-2000, “Konservasi Energi Selubung Bangunan pada Bangunan Gedung." [Online]. Available: http: //www.scribd.com/doc/73490184/SNI03-6389-2000-Konservasi-Energi-SelubungBangunan-Pada-Bangunan-Gedung.

[5] S. 03-6196-2000, "Prosedur Audit Energi pada Bangunan Gedung," 2008. [Online]. Available:

www.mmbeling. files. wordpress.com/2008/0 9/sni-03-6196-2000.pdf.

[6] M. . D. Egan, Concept in Thermal Comfort. New Jersey: Prentice Hall, 1975, pp. 4-58.

[7] T. Endangsih, Penerapan Hemat Energi Pada Kenyamanan Bangunan. Program Studi Teknik Arsitektur-Fakultas Teknik Universitas Budi Luhur, 2006. 